\title{
Field-scale variability of topsoil dehydrogenase and cellulase activities as affected by variability of some physico-chemical properties
}

\author{
Anna Piotrowska • Jacek Długosz • \\ Barbara Namysłowska-Wilczyńska • Ryszard Zamorski
}

Received: 7 June 2010 /Revised: 27 September 2010 / Accepted: 28 September 2010 / Published online: 12 October 2010

(C) The Author(s) 2010. This article is published with open access at Springerlink.com

\begin{abstract}
We have studied spatial field-scale variability of soil dehydrogenase (DH) and cellulase activities (CEL) and their relationship with variability of some physico-chemical properties at the surface horizon of the agricultural field. Soil samples were collected at 50 points from the upper $20 \mathrm{~cm}$ of soil. The activity of DH ranged between 0.77 and $1.5 \mu \mathrm{M} \mathrm{TPP} \cdot \mathrm{g}^{-1} \cdot \mathrm{h}^{-1}$ while CEL activity ranged from 0.8 to $1.94 \mu \mathrm{M}$ glucose $\cdot \mathrm{g}^{-1} \cdot 24 \mathrm{~h}^{-1}$. Concentrations of $\mathrm{C}_{\mathrm{ORG}}$ and TN varied from 8.5 to $31.7 \mathrm{~g} \cdot \mathrm{kg}^{-1}$ and from 0.94 to $3.56 \mathrm{~g} \cdot \mathrm{kg}^{-1}$, respectively. The soil data showed that spatial variability and semivariograms describe spherical and linear models with the nugget effect (DH, CEL, $\mathrm{C}_{\mathrm{ORG}}$ and $\mathrm{TN}$ ). Dehydrogenase activity was in the strong variability class, while cellulase activity was situated in the week variability class. Both $\mathrm{C}_{\mathrm{ORG}}$ and $\mathrm{TN}$ concentrations and $\mathrm{pH}_{\mathrm{KCl}}$ values were strongly spatially dependent with the percentage of total variance (sill) presents as nugget variance ranging from $8.9 \%$ to $16.1 \%$. Kriged maps displayed the lowest values of
\end{abstract}

\footnotetext{
A. Piotrowska $(\square) \cdot$ R. Zamorski

Department of Biochemistry,

Faculty of Agriculture and Biotechnology,

University of Technology and Life Sciences,

6 Bernardyńska St.,

85029 Bydgoszcz, Poland

e-mail: ap03@wp.pl

J. Długosz

Department of Soil Science and Soil Protection,

University of Technology and Life Sciences,

6 Bernardyńska St.,

85-029 Bydgoszcz, Poland

B. Namysłowska-Wilczyńska

Faculty of Civil Engineering, Institute of Geotechnics and

Hydroengineering, University of Technology,

Wybrzeże Wyspiańskiego 27,

50-370 Wrocław, Poland
}

CEL activities in the north-east of the area, while the south area showed the highest CEL activity. The DH activity values were irregularly distributed in the surface horizon of the studied soil and this behaviour did not correspond with the spatial distribution of other properties.

Keywords Cellulase $\cdot$ Dehydrogenase $\cdot$ Physico-chemical properties $\cdot$ Soil spatial variability $\cdot$ Geostatistics

\section{Introduction}

Soil spatial variability can be considered at different scales such as microscale, plot scale, field scale, landscape and regional scale (Parkin 1993; Kandeler et al. 2001; Lin et al. 2005; Baldrian et al. 2010). Spatial variability of soil parameters at the field scale have both theoretical and practical significance (Mulla and McBratney 2000) and can allow estimating real changes in soil properties for the proper management of soil resources (Usowicz 1999) and the use of the "precision agriculture". Soil variability of a cultivated field is often neglected and physico-chemical and biological parameters are measured by taking a single, quite often composite sample. Rarely pot or micro-field experiments reflect field variability (Usowicz et al. 2004).

The main factors controlling spatial variability of soil properties at the field scale are soil type, surface topography, and water distribution. Soil type depends on properties as texture, top soil thickness, organic matter content, $\mathrm{pH}$ and the nutrient status (Parkin 1993). A better understanding of the nature of spatial variability of various soil properties, as well as their relationship, should give real patterns of soil quality.

The investigations on some enzyme activities have been usually carried out as pot or micro-field experiments under more or less controlled conditions. There have been few 
studies on the spatial variability of soil enzyme activities, especially at field or regional scale (Bergstrom et al. 1998; Gaston et al. 2001; Kandeler et al. 2001; Asskin and Kizilkaya 2006; Smoliński et al. 2008; Gao et al. 2010; Baldrian et al. 2010). Enzyme activities show a broad spatial variability depending on the tested enzyme and on soil environmental conditions (Kandeler et al. 2001; Killham and Staddon 2002). Geostatistics has been used in soil science to estimate spatial variation of physico-chemical parameters (Usowicz et al. 2004; Brodský et al. 2004; Iqbal et al. 2005; Jung et al. 2006) but it has been rarely used to evaluate spatial-temporal fluctuations of biological parameters (Parkin 1993; Goovaerts 1998; Morris 1999; Saetre 1999; Mulla and McBratney 2000).

Dehydrogenase activity (DH) plays a role in the biological oxidation of soil organic matter and cellulase activity (CEL) is important in soil $\mathrm{C}$ cycle (Makoi and Ndakidemi 2008) and thus it is important to study spatial variability of these enzyme activities.

The aim of the investigation was to determine the spatial distribution of dehydrogenase and cellulase activities in the surface horizon of an acid soil and to compare them with some physico-chemical properties of considerably differentiated values. The acid soil was selected because it represents the soils in Poland.

\section{Material and methods}

The site description and the sampling procedure

The studied field (50 ha) with varied relief (drop of about $20 \mathrm{~m}$ ) was located at the Sepopolska Plain, near the Budniki Village, Warmia region, northern Poland $\left(54^{\circ} 11^{\prime}\right.$ $\left.47^{\prime \prime} \mathrm{N}, 20^{\circ} 38^{\prime} 35^{\prime \prime} \mathrm{E}\right)$. Soil sampling scheme carried out in an irregular grid pattern is shown on Fig. 1. The soils of the area are Eutric Cambisols, District Cambisols and Gleyic Phaeozems (IUSS Working Group WRB 2007). We collected 50 soil samples in approximately regular intervals $(50 \mathrm{~m})$ across the field. Each sample consisted of 30 individual sub-samples ( $30 \mathrm{~g}$ each) taken randomly from a circle area with a radius of $10 \mathrm{~m}$ from the node point. The only exception was some node points situated near the field border where sub-samples were collected on the one side of the node point. The samples were taken after harvest of winter wheat (Triticum aestivum L.) and tillage and prior seeding winter rape (Brassica napus L.). Field-moist samples were sieved $(<2 \mathrm{~mm})$ and stored at $4{ }^{\circ} \mathrm{C}$ in a plastic box for not less than 2 days to stabilize microbial activity and then analyzed for dehydrogenase and cellulase activities. Soil samples were analyzed for physical and chemical properties after air-drying at room temperature and sieving $(<2 \mathrm{~mm})$.

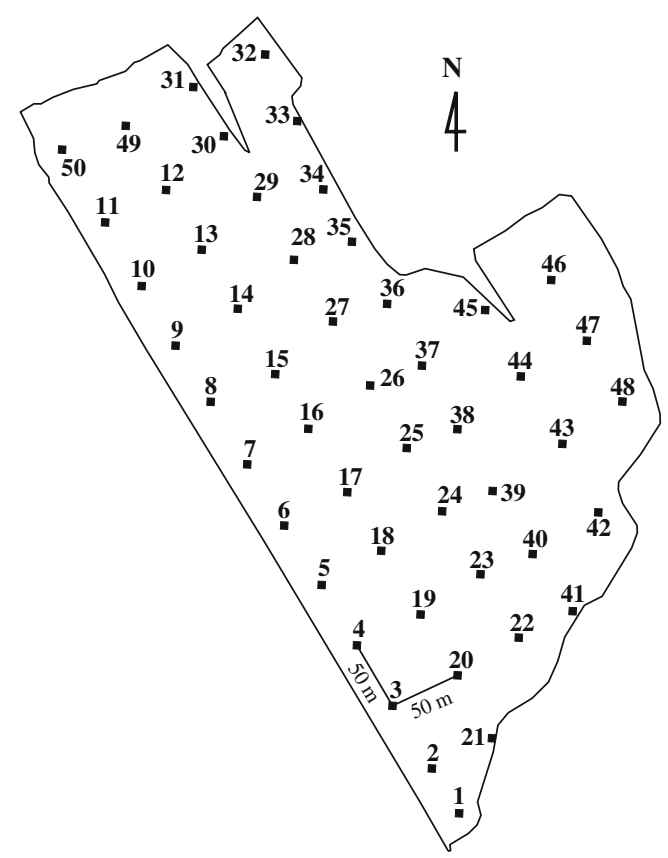

Fig. 1 The soil sampling scheme

Soil analyses

Dehydrogenase activity (DH) was determined according to Thalmann (1968) with some minor modifications. Soil (1 g) was incubated for $24 \mathrm{~h}$ with 2, 3, 5-triphenyltetrazolium chloride (TTC, $3 \mathrm{mgml}^{-1}$ ) at $27^{\circ} \mathrm{C}, \mathrm{pH}$ 7.6. The produced triphenylformazan (TPP) was extracted with acetone and measured spectophotometrically at $546 \mathrm{~nm}$. Dehydrogenase activity was expressed as $\mu \mathrm{M}$ TPP $\mathrm{g}^{-1} \mathrm{~d}$.m. soil $\mathrm{h}^{-1}$. Cellulase activity (CEL) was assayed as reported by Schinner and von Mersi (1990). Low molecular products and sugars resulting from the enzyme degradation of carboxymethylcellulose (Sigma Aldrich, $7 \mathrm{mgml}^{-1}$ ) for $24 \mathrm{~h}$ at $50^{\circ} \mathrm{C}$ and $\mathrm{pH} 5.5$ were determined spectophotometrically at $690 \mathrm{~nm}$. Cellulase activity was expressed as $\mu \mathrm{M}$ glucose $\cdot \mathrm{g}^{-1} \mathrm{~d}$.m. soil $\cdot 24 \mathrm{~h}^{-1}$. Control tests with autoclaved soils were included in all enzyme assays to evaluate the spontaneous or abiotic transformation of substrates. Both enzyme activities are means of three replicates and are expressed on a moisture-free basis. Moisture content was determined by drying the soil samples at $105^{\circ} \mathrm{C}$ for $24 \mathrm{~h}$.

Chemical analyses were performed on air dried and sieved $(<2 \mathrm{~mm})$ soil samples according to standard methods (Burt 2004) and each sample was analyzed in triplicate. According to the USDA (Soil Survey Staff 1999), soil samples were classified as loam (48\% of samples), fine sandy loam ( $26 \%$ of samples), clay loam (18\% of samples), sandy clay loam ( $6 \%$ of samples) and sandy loam ( $2 \%$ of samples). Clay fraction content ranged from $8 \%$ to $39 \%$. A particle size distribution analysis was carried out by the pipette method; the $\mathrm{pH}$ in $1 \mathrm{~mol} \mathrm{KCl} \cdot \mathrm{dm}^{3}$ was measured by 
potentiometric method in 1:2.5 soil : solution suspensions; total organic carbon $\left(\mathrm{C}_{\mathrm{ORG}}\right)$ and total nitrogen $(\mathrm{TN})$ were determined by the dry combustion $\mathrm{CN}$ analyser (Vario Max $\mathrm{CN})$.

\section{Statistical and geostatistical analyses}

Data were evaluated with classical statistical methods (STATISTICA v. 9.0) calculating arithmetic and geometric means, standard deviation, coefficient of variation as well as skewness and kurtosis. Geostatistical calculations included empirical semivariograms graphs and theoretical mathematical model of variograms. The following geostatistic parameters were considered: nugget, sill variance, range of influence. To classify the spatial dependence of soil properties we calculated the percentage of total variance (sill) presents as random variance $[(\mathrm{Co} / \mathrm{Co}+\mathrm{C}) \cdot 100]$ (Cambardella et al. 1994). We used the method of point kriging proposed by Davis (1986) and the calculations were done using Isatis software (Geovariance Co.). The maps illustrating the spatial variance of determined parameters were drawn on the basis of semivariograms.

A semivariogram is a measure traditionally defined as half of the quadratic mean of the difference between two values of a measurable parameters (the considered regionalized variable), separated by the distance $\mathrm{h}$ (Burgess and Webster 1980). The semivariogram $\gamma(\mathrm{h})$ was estimated using the equation:

$\gamma(h)=\frac{1}{2 N(h)} \sum_{i=1}^{N(h)}\left(x_{i}-y_{i}\right)^{2}$

where:

$N(h)$ is the number of sample pairs; $x_{\mathrm{i}}, y_{\mathrm{i}}$ are the values of the considered variable in a pair (respectively at its beginning and end).

Kriging is a technique of determining the mean value used for "local estimation" purposes, in which only the data close to the tested area (search area-kriging neighbourhood) are used in the estimation (Mulla 1989). The geostatistical empirical variogram models were proposed for the area where parameters were determined. The commonly used kriging estimators are: ordinary kriging (when the arithmetic mean is unknown) and simple kriging (when the average estimated for the whole investigated sampling population or for local estimations is known). The value of the investigated parameter in the location $x_{\mathrm{o}}$ was estimated using ordinary point kriging on the basis of $n$ neighbouring sampling points considering $x_{\alpha}$ a linear relationship with weights $w_{\alpha}$ :

$Z^{*}\left(x_{o}\right)=\sum_{\alpha=1}^{n} w_{\alpha} Z\left(x_{\alpha}\right)$
Geostatistical analyses are based on original (input) databases with values of coordinates $\mathrm{X}, \mathrm{Y}$ and $\mathrm{Z}$ specifying sampling (measurements, observations, etc.) and parameter (regionalized variables) locations. The basic statistics of the investigated parameters are roughly estimated and a structural analysis of their variation, including the calculation of isotropic and directional empirical variograms (covariograms), is carried out. Then the (co-)variograms are modelled by theoretical functions (the so-called geostatistical models) and the adopted (co-)variogram models are cross-validated using ordinary point kriging (Mulla and McBratney 2000).

\section{Results}

Descriptive statistics of soil parameters under study

Basic statistical properties of the measurements within the studied area are presented in Table 1. Results of all investigated parameters showed a normal distribution according to Shapiro-Wilk test (Statistica v. 9.0), and for this reason data were not transformed.

The DH activity of the soil surface ranged from 0.77 to $1.5 \mu \mathrm{M} \mathrm{TPP} \cdot \mathrm{g}^{-1} \cdot \mathrm{h}^{-1}$ with mean value of $\mu \mathrm{M} \mathrm{TPP} \cdot \mathrm{g}^{-1} \cdot \mathrm{h}^{-1}$, while cellulase activity ranged from 0.8 to $1.94 \mu \mathrm{M}$ glucose $\cdot \mathrm{g}^{-1} \cdot 24 \mathrm{~h}^{-1}$ with mean of $1.06 \mu \mathrm{M}$ glucose $\cdot \mathrm{g}^{-1} \cdot 24 \mathrm{~h}^{-1}$. Most of DH activity was similar to the mean value, as shown by the fact that median and the mean values were similar, suggesting almost symmetric results distribution. Low kurtosis value indicated that the $\mathrm{DH}$ activity distribution was similar to the normal one.

Dispersion analysis of cellulase activity was characterized by a very high concentration around the mean value, which was confirmed by leptokurtic distribution (kurtosis 10.24), underlining a slim distribution. Distribution of CEL activity indicated that most of soil samples had enzyme activity lower than the mean value, which was confirmed by a high skewness value. The variation of coefficients obtained for DH was low and for CEL was moderate according to the classes based on coefficient of variation $(\mathrm{CV}$; \%) values proposed by Wilding (1985) for assessing soil properties variability.

The $\mathrm{C}_{\mathrm{ORG}}$ and $\mathrm{TN}$ contents of the top soil ranged widely from 8.5 to 31.7 and from 0.94 to $3.56 \mathrm{~g} \cdot \mathrm{kg}^{-1}$, respectively (Table 1). A significant differentiation of the results was indicated by the standard deviation value and variation coefficient, showing that their differentiation was equal on the studied area under. Additionally, the very high variance value (14.46) showed a significant distribution of TOC concentration. However, the dispersion analyses of $\mathrm{C}_{\mathrm{ORG}}$ concentrations revealed a high focusing around the mean value, and this was confirmed by leptokurtic distribution (kurtosis 11.05), while TN concentrations distribution was similar to the normal one. 
Table 1 Statistics of soil properties $(n=50)$

$S D$ standard deviation, $C V(\%)$ coefficient of variation, $\mathrm{DH}$ dehydrogenase activity $\left(\mu \mathrm{M} \mathrm{TPP} \cdot \mathrm{g}^{-1} \cdot \mathrm{h}^{-1}\right), C E L$ cellulase activity $(\mu M$ glucose $\left.g^{-1} \cdot 24 h^{-1}\right), C_{O R C}$ organic carbon $\left(\mathrm{g} \cdot \mathrm{kg}^{-1}\right), \mathrm{TN}$ total nitrogen content $\left(g \cdot \mathrm{kg}^{-1}\right)$

\begin{tabular}{lcccccccc}
\hline & $\mathrm{DH}$ & $\mathrm{CEL}$ & $\mathrm{C}_{\mathrm{ORG}}$ & $\mathrm{TN}$ & $\mathrm{pH}_{\mathrm{KCl}}$ & Sand & Silt & Clay \\
\hline Minimum & 0.77 & 0.80 & 8.50 & 0.94 & 3.77 & 33.2 & 19.9 & 8.0 \\
Maximum & 1.50 & 1.94 & 31.70 & 3.56 & 6.70 & 69.1 & 45.4 & 39.0 \\
Arithmetical mean & 1.07 & 1.06 & 13.36 & 1.43 & 5.03 & 46.6 & 32.6 & 20.8 \\
Geometrical mean & 1.54 & 1.04 & 12.36 & 1.38 & 4.98 & 45.9 & 32.14 & 19.78 \\
Variance & 0.02 & 0.03 & 14.46 & 0.17 & 0.47 & 71.85 & 28.5 & 40.25 \\
SD & 0.15 & 0.18 & 3.80 & 0.41 & 0.69 & 8.48 & 5.34 & 6.34 \\
Median & 1.09 & 1.01 & 12.40 & 1.33 & 5.09 & 44.55 & 33.35 & 21.0 \\
CV (\%) & 14.2 & 17.4 & 28.47 & 28.93 & 13.68 & 18.19 & 16.37 & 30.5 \\
Kurtosis & 0.67 & 10.24 & 11.05 & 1.27 & -0.18 & -0.18 & -0.11 & 0.26 \\
Skewness & 0.36 & 2.45 & 2.77 & 3.10 & 0.13 & 0.56 & -0.25 & 0.32 \\
\hline
\end{tabular}

The $\mathrm{pH}(\mathrm{KCl})$ ranged from 3.77 to 6.70 with geometrical mean of 4.98. A significant dispersion of $\mathrm{pH}$ values was confirmed by high GD, the variance values and the negative kurtosis of -0.18 (a flattened distribution). Similarly, the negative kurtosis values were obtained for both sand and silt contents confirming that the relative data was more flattened than the normal one. As regards the granulometric fractions, the highest differentiation was noted for clay, with a wide range of values (8.0-39.0\%), high $\mathrm{SD}$ and variance and by the high $\mathrm{CV}$ value of $30.5 \%$.

The analysis of correlation showed no significant coefficient for most of investigated parameters (data not presented). Only $\mathrm{C}_{\mathrm{ORG}}$ and $\mathrm{TN}$ were significantly and positively correlated with the clay content $(r=0.45-0.47 ; p<$ $0.05 ; n=50)$ and significantly but negatively correlated with the sand content $(r=-0.50-0.52 ; p<0.05)$. No significant correlation was found between $\mathrm{pH}_{\mathrm{KCl}}$ values and enzyme activities, while $\mathrm{pH}_{\mathrm{KCl}}$ values were positively correlated with the clay content $(r=0.39 ; p<0.05 ; n=50)$ and negatively correlated with the sand content $(r=-0.32 ; p<0.05 ; n=50)$.

Spatial variability of studied properties

Generally, the soil data showed a spatial dependence (Table 2, Figs. 2-3). All semivariograms exhibited a spatial structure that could be best described by spherical models for $\mathrm{C}_{\mathrm{ORG}}$ and $\mathrm{TN}$ contents, $\mathrm{DH}$ activity and clay percentage, while spherical/linear models described CEL activity and soil reaction. Spatial dependence of all parameters except clay content showed short-range variability represented by nugget effect. Parameters for these models are given in Table 2 and Fig. 2a-f.

The spatial dependence of the data was confirmed by sill variance $(\mathrm{Co}+\mathrm{C})$, composed of structural $(\mathrm{C})$ and nugget variance $(\mathrm{Co})$, except for the clay fraction content which showed only structural variance. Almost all parameters displayed a low nugget variance $[\mathrm{Co} /(\mathrm{Co}+\mathrm{C})] \cdot 100$ ranging from $8.9 \%$ to $21.2 \%$. Nugget semivariances for the CEL activity were very high as compared with sills and nugget effects accounting for $94.7 \%$ of the total variance.

The spatial variability of the studied parameters was categorized into classes based on the percentage of total variance (sill) presents as random variance, proposed by Cambardella et al. (1994). Almost all parameters indicated a strong spatial variability (less than $25 \%$ spatial variability) except for the CEL activity which had a poor spatial variability (above $75 \%$ spatial variability). According to Cambardella et al. (1994), the variability of weakly spatially dependent parameters might be controlled by factors, such as application of fertilizers and tillage, whereas

Table 2 Parameters of variogram models

\begin{tabular}{|c|c|c|c|c|c|c|}
\hline & $\mathrm{DH}$ & CEL & $\mathrm{C}_{\mathrm{ORG}}$ & $\mathrm{TN}$ & $\mathrm{pH}$ & Clay \\
\hline Model & Sph, NE & Sph, L & Sph, NE & Sph, NE & Sph, L & Sph \\
\hline $\mathrm{Co}$ & 0.0045 & 0.018 & 1.417 & 0.0167 & 0.046 & - \\
\hline$(\mathrm{Co}+\mathrm{C})$ & 0.0212 & 0.019 & 15.917 & 0.184 & 0.139 & 35.44 \\
\hline$[\mathrm{Co} /(\mathrm{Co}+\mathrm{C})] 100$ & $21.2 \%$ & $94.7 \%$ & $8.9 \%$ & $9.0 \%$ & $16.1 \%$ & - \\
\hline Range (m) & 84.3 & 93.3 & 93.3 & 93.3 & 81.3 & 93.3 \\
\hline${ }^{\mathrm{d}} \mathrm{SD}$ & $\mathrm{S}$ & $\mathrm{W}$ & $\mathrm{S}$ & $\mathrm{S}$ & $\mathrm{S}$ & - \\
\hline
\end{tabular}

Co nugget variance, $C$ structural variance, $C o+C$ sill, $S p h$ spherical model, $N E$ nugget effect, $L$ linear model, $S D$ spatial dependence, $S$ strong, $W$ week, $D H$ dehydrogenase activity $\left(\mu \mathrm{M}\right.$ TPP $\left.\cdot \mathrm{g}^{-1} \cdot \mathrm{h}^{-1}\right), C E L$ cellulase activity $\left(\mu \mathrm{M}\right.$ glucose $\left.\cdot \mathrm{g}^{-1} \cdot 24 \mathrm{~h}^{-1}\right), C_{O R G}$ organic carbon content $\left(\mathrm{g} \cdot \mathrm{kg}^{-1}\right), T N$ total nitrogen content $\left(\mathrm{g} \cdot \mathrm{kg}^{-1}\right)$ 
Fig. 2 Experimental semivariograms of: a dehydrogenase activity $\left(\mu \mathrm{M} \mathrm{TPP} \cdot \mathrm{g}^{-1} \cdot \mathrm{h}^{-1}\right)$, b cellulase activity ( $\mu \mathrm{M}$ glucose $\left.\cdot \mathrm{g}^{-1} \cdot 24 \mathrm{~h}^{-1}\right), \mathbf{c}$ $\mathrm{C}_{\text {ORG }}$ content $\left(\mathrm{g} \cdot \mathrm{kg}^{-1}\right), \mathbf{d} \mathrm{TN}$ content $\left(\mathrm{g} \cdot \mathrm{kg}^{-1}\right)$, e $\mathrm{pH}$ and $\mathbf{f}$ clay percentage a)

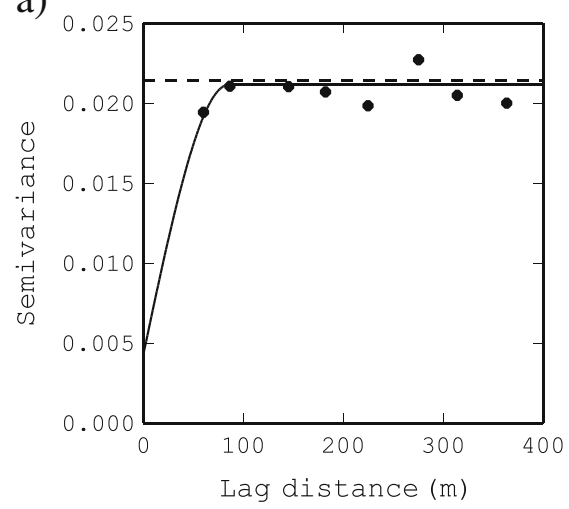

c)

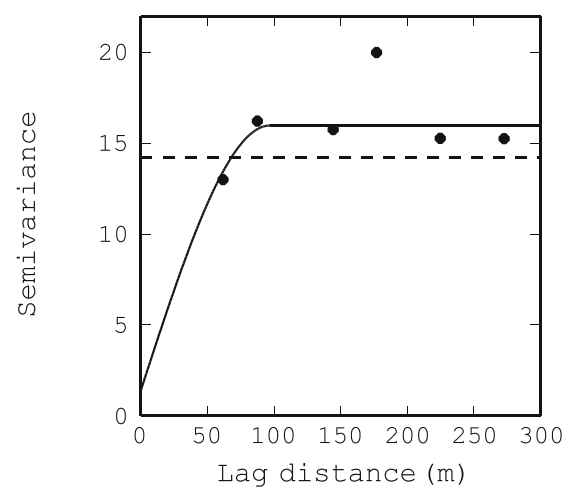

e)

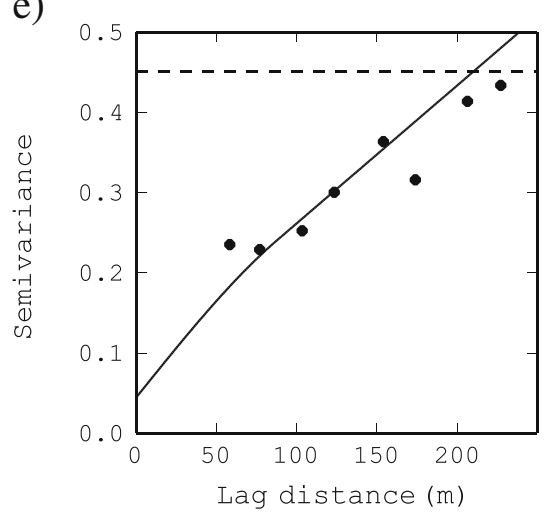

b)

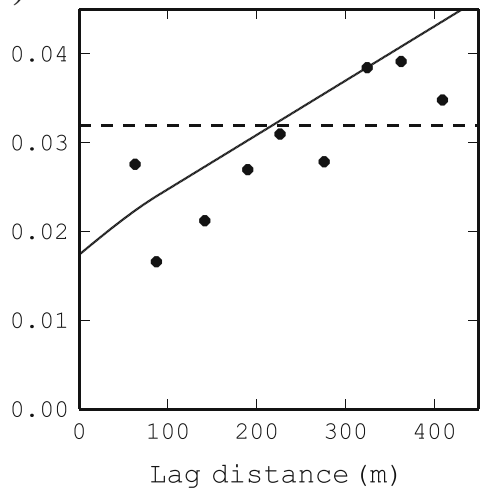

d)

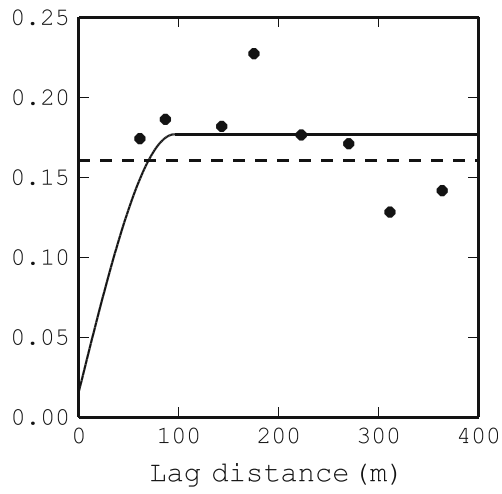

f)

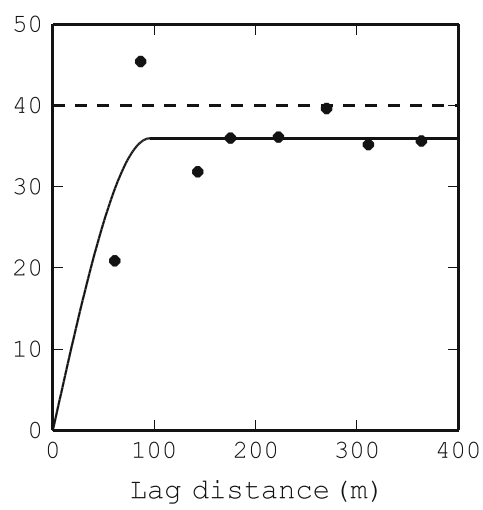

strongly spatially dependent parameters are influenced by variations in soil characteristics, such as texture and mineralogy. The sampling scheme and statistical methods used in this study however have not allowed to discriminating these two sources of variability.

The ranges of the influence calculated for the microbial parameters measured in this study ranged from 81.3 to $93.3 \mathrm{~m}$. Since the samples separated by a distance smaller than the range are related spatially (Flatman and Yfantis 1984; Cambardella et al. 1994), the range values of this study showed that all variables were spatially autocorrelated and either the sampling distance $(50 \mathrm{~m})$ was suitable or samples might be even separated by the distance bigger than $50 \mathrm{~m}$.
Semivariograms models of some the studied parameters were used to generate kriged maps (Fig. 3a-d). The spatial trends in the CEL activity distribution were very clear. The lowest activities were situated in the north-east of the area, while the highest activities were in the south of area. A band of a relatively average soil CEL activity run diagonally across the field, from the south-east to the north-west. The DH activities (Fig. 3b) were irregularly distributed in the surface soil and they did not correspond with topographical features of the area or the mode of spatial distribution of other properties. Kriged maps of $\mathrm{C}_{\mathrm{ORG}}$ and $\mathrm{TN}$ contents (Fig. 3c, d) showed approximately a similar pattern distribution and their concentrations were minimal in the north part of the area. Most of the highest 
Fig. 3 Contour maps for soil parameters: a cellulase activity $\left(\mu \mathrm{M}\right.$ glucose $\left.\cdot \mathrm{g}^{-1} \cdot 24 \mathrm{~h}^{-1}\right)$, b dehydrogenase activity $(\mu \mathrm{M}$ TPP.g $\left.{ }^{-1} \cdot h^{-1}\right), \mathbf{c}_{\text {ORG }}$ content $\left(\mathrm{g} \cdot \mathrm{kg}^{-1}\right)$ and $\mathbf{d} \mathrm{TN}$ content $\left(\mathrm{g} \cdot \mathrm{kg}^{-1}\right)$
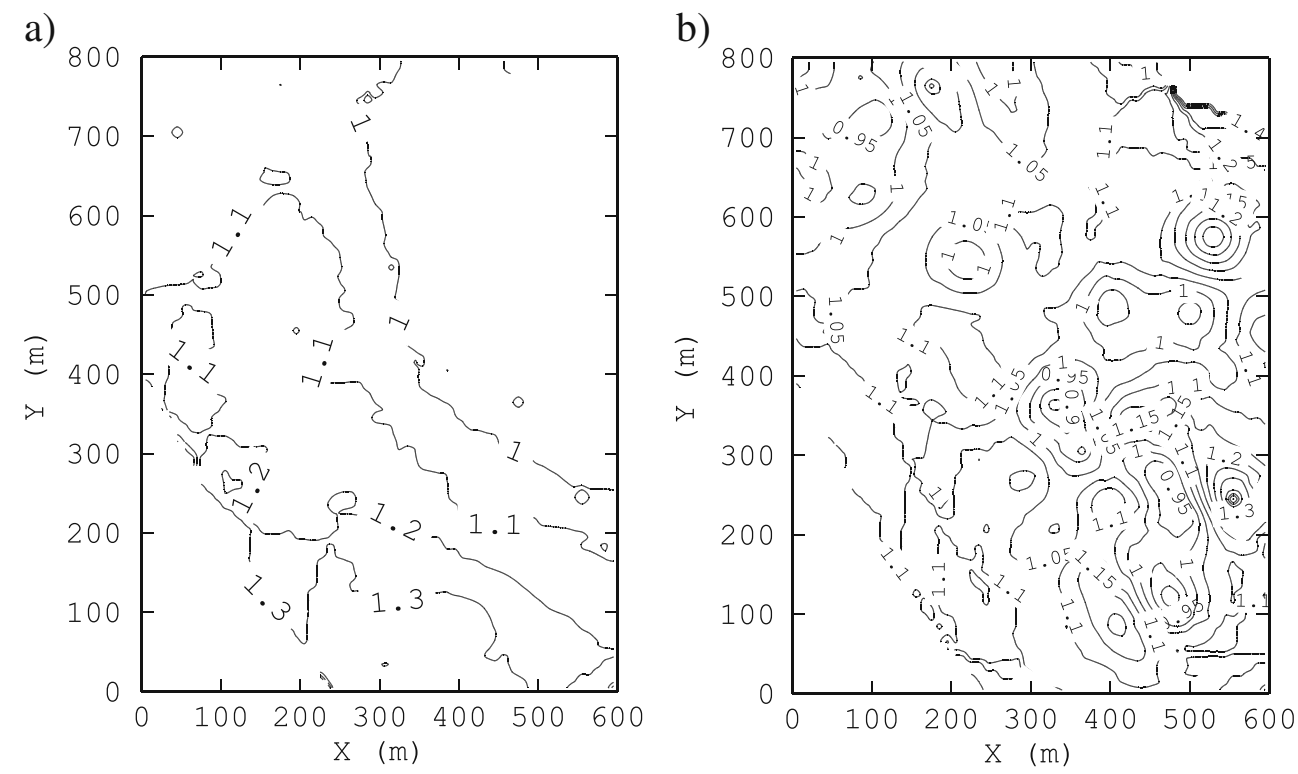

c)

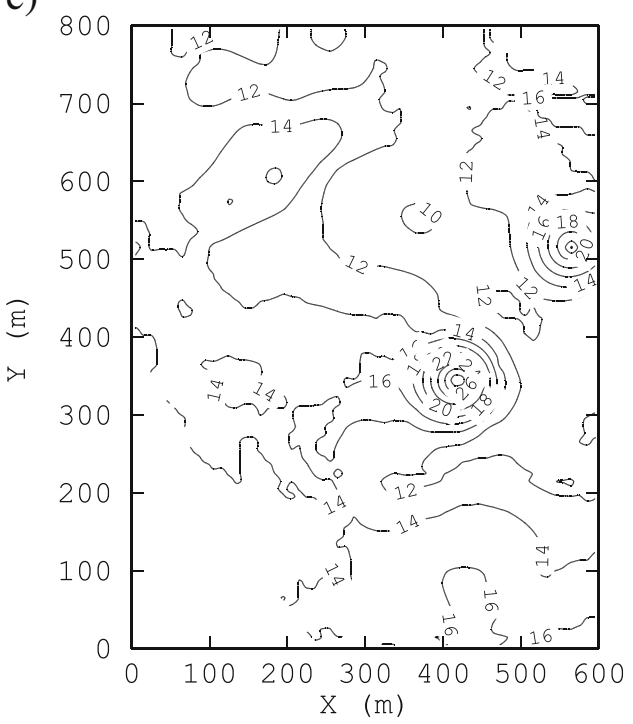

d)

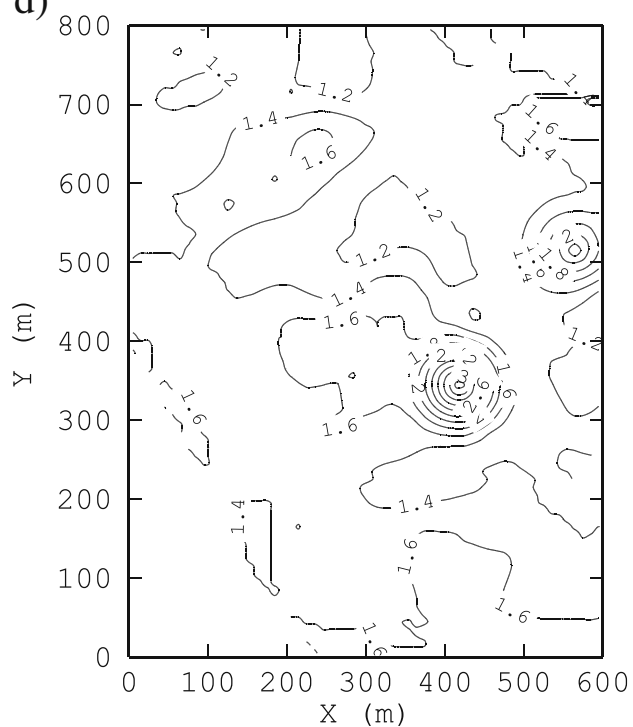

values of $\mathrm{C}_{\mathrm{ORG}}$ and $\mathrm{TN}$ were in the area where Gleyic Phaeozems (IUSS Working Group WRB 2007) occurred (see Fig. 1, values around sampling point no 24). Since the correlation between $\mathrm{C}_{\mathrm{ORG}}$ and $\mathrm{TN}$ and clay was rather low ( $r=0.45-0.47 ; p<0.05 ; n=50$; data not presented) only partial co-occurrence of these variables was shown on the maps. In the area where co-occurrence was not observed, additional factors may control the distribution of both properties.

\section{Discussion}

The spatial variability of soil properties can be high, moderate and low and depends on of both natural factors and human activities. According to Mulla and McBratney (2000), pH and porosity usually reveal a low spatial variability, while organic matter content and clay content are characterized by a moderate to high variability. As stated by Parkin (1993), soil microbiological and biochemical parameters usually reveal a high spatial variability. For instance, soil DH activity was moderately dependent (CV $37 \%$ ) on the field grid ( 250 by $250 \mathrm{~m}$ ) (Cambardella et al. 1994) but it showed a high spatial variability, ranging from $47 \%$ to $70 \%$, in the 28 ha area (Aon and Colaneri 2001). However, statistical analysis on enzyme activities showed a relatively small variability as revealed by $\mathrm{SD}$ values and by the small variation coefficients $(\mathrm{CV}=14.2$ and $17.4 \%$, for $\mathrm{DH}$ and CEL, respectively) according to the classification of soil properties based on $\mathrm{CV}$ values reported by Wilding (1985). According to this classification the DH activities were in the upper limit of the small variability class while CEL activities were in the lower limit of the moderate class variability. Bergstrom et al. (1998) reported a CV value of 
$12 \%$ for the soil $\mathrm{DH}$ activity in the Ap horizon of a conventionally tilled field. Nearly $30 \%$ of $\mathrm{CV}$ values for $\mathrm{C}_{\mathrm{ORG}}$ and TN contents and above $30 \%$ for the clay content indicated a moderate variability of these parameters. Lower $\mathrm{CV}$ values for $\mathrm{C}_{\mathrm{ORG}}(19.1 \%)$ and $\mathrm{TN}(23.0 \%)$ content were reported by Bonmati et al. (1991). The variation coefficient $(13.68 \%)$ for $\mathrm{pH}$ in our study agrees with what reported by Cavigelli et al. (2005), who showed a short-range spatial variability of soil $\mathrm{pH}$ values ranging from $2 \%$ to $15 \%$.

Despite CEL and DH activities showed similar means, standard deviation values ( 0.15 and 0.18 , respectively) and changeability coefficients (discussed above) they showed different distribution patterns, which in the case of $\mathrm{DH}$ activity was close to a symmetrical one (skewness 0.36 ) but rather flat (kurtosis 0.67), whereas in the case of CEL activity was more agglomerated (kurtosis 10.2) with the skewness (2.45) towards high enzyme activities (Table 1).

The kriged map of DH activity (Fig. 3b) indicated that most samples had low enzyme activity and a few samples high enzyme activity. It can be hypothesized that the latter were due to the non-homogenous dispersion of enzymatically active microsites in the soil with only a few microsites with high DH activity. A very high nugget effect of the CEL activity (Table 2) was probably due to nonhomogenous occurrence of the enzyme due to the patchy diffusion of post-harvest residues in the surface soil. Postharvest residues are the main substrates for cellulases.

According to the classification based on the percentage of total variance (sill) presents as random variance (Cambardella et al. 1994) almost all of the investigated properties were spatially dependent (values smaller than 25\%), while CEL activity exhibited a week spatial variability (Table 2). Röver and Kaiser (1999) showed a moderate spatial variability for some physical, chemical, and biological soil properties. Similar observations were also reported by Staddon et al. (2004) for DH activities in non-till soil under wheat cover crop where the structural variance amounted for $70.7 \%$. Higher nugget effect was displayed by $\mathrm{DH}$ activity for no-till field $(62.7 \%)$ (Cambardella et al. 1994) and for Cambisols under winter wheat (68.4\%) (Smoliński et al. 2008), suggesting that DH activity was poorly spatially dependent.

As suggested by Bergstrom et al. (1998), the knowledge of spatial variability of soil enzyme activities can give information on the needed sampling density, and help to interpret ecological meaning of enzyme activities. They suggested that the scale of sampling was too large for the properties that were not spatially dependent (e.g. dehydrogenase activity) and probably a sampling distance of $1 \mathrm{~m}$ rather than $10 \mathrm{~m}$ would be more appropriate. In the case of our study a comparison of range values of the studied properties indicated that a less intensive sampling scheme can be used than the one applied $(50 \mathrm{~m})$. Flatman and Yfantis (1984) suggested a soil sample distance from one fourth to one half of the range. The range of some properties have been found to markedly differ (Amador et al. 1997; Gaston et al. 2001; Stenger et al. 2002; Brodský et al. 2004; Așkin and Kizilkaya 2006). Significantly higher ranges values were observed for organic $\mathrm{C}$ content than for arylsuphatase and phosphates activities by Bergstrom et al. (1998). A shorter range for dehydrogenase activity $(23,51$ and $60 \mathrm{~m})$ than our values was reported by Staddon et al. (2004), Cambardella et al. (1994) and Smoliński et al. (2008), respectively. According to Morris (1999) the differences in geostatistical analyses (structural and nugget variance, range) mainly depend on the sample size and the sampling distance.

The high variability of $\mathrm{C}_{\mathrm{ORG}}$ and $\mathrm{TN}$ contents, soil $\mathrm{pH}$ and texture did not affect the two enzyme activities (no significant correlation coefficients were found). The soil $\mathrm{pH}$ has been suggested to be the best predictor of $\mathrm{DH}$ activity (Thalmann 1968; Rossel et al. 1997) and it accounted for the highest proportion of the observed variability in the DH activity (Quilchano and Maraňón 2002). Probably the adsorption of soil microorganisms to soil particles protected DH activity and extracellular cellulase against to changes of $\mathrm{pH}$ values. On the other hand, immobilization of extracellular enzymes on soil colloids may decrease the enzyme activity by masking enzyme active sites while in the case of adsorbed microorganisms the diffusion of the substrate can be a limiting factor for the intracellular enzyme activity (Nannipieri et al. 2002). This may explain the lack of significant correlation between $\mathrm{DH}$ and $\mathrm{CEL}$ activities and $\mathrm{C}_{\mathrm{ORG}}, \mathrm{TN}$ and clay content while previous studies have found either positive or negative significant correlations between enzyme activities and some soil properties (e.g. Bonmati et al. 1991; Leirós et al. 2000; Aon and Colaneri 2001; Melero et al. 2006). Another possible explanation is that by Quilchano and Maraňón (2002), suggesting that soil microorganisms are not $\mathrm{C}$ and $\mathrm{N}$ limited, and thus $\mathrm{DH}$ activity did not respond to changes in $\mathrm{C}$ and $\mathrm{N}$ contents.

Changes in the enzyme activities preceded changes in organic matter content and their spatial activity was related to that in the organic C content (Bergstrom et al. 1998). Enzyme activity may increase with organic carbon content because microbial activity depends on the supply of organic C as a substrate (Bergstrom et al. 1998). In our study, however, the enzymatic activities were no correlated with $\mathrm{C}_{\mathrm{ORG}}$ and $\mathrm{TN}$ concentrations. Different soil types and different management practices may also explain different reports. Mummey et al. (2002) suggested that plants cover plays a main role in establishing soil heterogeneity and in regulating ecological processes due to plant nutrient demands. Similarly, Kizilkaya and Așkin (2007) confirmed that plants contributed to soil heterogeneity by their effects on soil moisture, aeration and $\mathrm{pH}$ and by the litter type and 
distribution. Moreover, plants can influence the composition and biomass of soil microflora (Bezemer et al. 2006) and the rate of microbial processes (Bengtson et al. 2006). It can be concluded that probably the differences in microbial communities occurring among different soils can partly explain the differences in the obtained data.

\section{Conclusions}

On the basis of conventional and geostatistical analysis of our results as well as cited in the bibliography it can be concluded that the spatial variability of properties of arable soils is very complex. Since the variability is influenced by natural and anthropogenic factors it is problematic to distinguish different effects. Both dehydrogenase and cellulase activities showed a patchy distribution not related to the other measured soil properties.

Because the spatial structure of soil properties is complex and contrasting ranges values have been reported, future research should concern the studied area size and the sampling points intervals. Thus, the most appropriate sampling scheme, and separation distance between sampling position for the future data collection is of special importance and should be done in preliminary studies. Results showed that for all investigated parameters the sample grid was suitable. However less intensive sampling scheme might be used than that we have applied in this study. Soil heterogeneity and the complexity of the spatial distribution of soil properties with the contrasting results of earlier studies indicate that the results of spatial variability structure are rather site-specific and this kind of studies is only of local importance.

Acknowledgements The authors are truly indebted to Mariusz Michalski for providing a production field for the experiments and for his co-operation in the sampling procedure.

Open Access This article is distributed under the terms of the Creative Commons Attribution Noncommercial License which permits any noncommercial use, distribution, and reproduction in any medium, provided the original author(s) and source are credited.

\section{References}

Amador JA, Glucksman AM, Lyons JB, Görres JH (1997) Spatial distribution of soil phosphatase activity within a Riparian forest. Soil Sci 162(11):808-825

Aon MA, Colaneri AC (2001) II. Temporal and spatial evolution of enzymatic activities and physico-chemical properties in an agricultural soil. Appl Soil Ecol 18:255-270

Așkin T, Kizilkaya R (2006) Assessing spatial variability of soil enzyme activities in pasture topsoils using geostatistics. Eur J Soil Biol 42:230-237

Baldrian P, Merhautová V, Cajthaml T, Petránková M, Šnajdar J (2010) Small-scale disturbance of extracellular enzymes, fungal, and bacterial biomass in Quercus petraea forest topsoil. Biol Fertil Soils 46:717-726

Bengtson P, Falkengren-Grerup U, Bengtsson G (2006) Spatial distribution of plants and gross $\mathrm{N}$ transformation rates in a forest soil. J Ecol 94:754-764

Bergstrom DW, Monreal CM, Millette JA, King DJ (1998) Spatial dependence of soil enzyme activities along a slope. Soil Sci Soc Am J 62:1302-1308

Bezemer TM, Lawson CS, Hedlund K, Edwards AR, Brook AJ, Igual JM, Mortimer SR, van der Putten WH (2006) Plant species and functional group effects on abiotic and microbial soil properties and plant-soil feedback responses in two grasslands. J Ecol 94:893-904

Bonmati M, Ceccanti B, Nannipieri P (1991) Spatial variability of phosphatase, urease, protease, organic carbon and total nitrogen in soil. Soil Biol Biochem 23(4):391-396

Brodský L, Vaněk V, Borůvka L, Száková J (2004) Consistency of spatial dependence of soil chemical properties in two fields: a geostatistical study. Plant Soil Environ 50:507-512

Burgess TM, Webster R (1980) Optimal interpolation and isarithmic mapping of soil properties. I. The semi-variogram and punctual kriging. J Soil Sci 31:315-331

Burt R (2004) Soil Survey laboratory methods manual, Soil Survey Investigations Report No. 42, version 4.0, USDA-NRCS, Lincoln, Nebraska

Cambardella CA, Moorman TB, Novak JM, Parkin TB, Karlen DL, Turco RF, Konopka AE (1994) Field-scale variability of soil properties in Central Iowa soils. Soil Sci Soc Am J 58:15011511

Cavigelli MA, Lengnick LL, Buyer JS, Fravel D, Handoo Z, McCarty G, Millner P, Sikora L, Wright S, Vinyard B, Rabenhorst M (2005) Landscape level variation in soil resources and microbial properties in a no-till corn field. Appl Soil Ecol 29:99-123

Davis JC (1986) Statistics and data analysis in geology. Wiley, New York

Flatman GT, Yfantis AA (1984) Geostatistical strategy for soil sampling: the survey and the census. Environ Monit Assess 4:335-349

Gao Y, Mao L, Miao C, Zhou P, Cao J, Zhi Y, Shi W (2010) Spatial characteristics of soil enzyme activities and microbial community structure under different land uses in Chongming Island, China: geostatistical modelling and PCR-RAPD method. Sci Total Environ 408:3251-3260

Gaston LA, Locke MA, Zablotowicz RM, Reddy KN (2001) Spatial variability of soil properties and weed populations in the Mississippi Delta. Soil Sci Soc Am J 65:449-459

Goovaerts P (1998) Geostatistical tools for characterizing the spatial variability of microbiological and physico-chemical soil properties. Biol Fertil Soils 27:315-334

Iqbal J, Thomasson JA, Jenkins JN, Owens PR, Whisler FD (2005) Spatial variability analysis of soil physical properties of alluvial soils. Soil Sci Soc Am J 69:1338-1350

IUSS Working Group WRB (2007) World reference base for soil resources 2006-first update 2007. World soil resources reports No. 103. FAO, Rome

Jung WK, Kitchen NR, Sudduth KA, Anderson SH (2006) Spatial characteristics of claypan soil properties in an agricultural field. Soil Sci Soc Am J 70:1387-1397

Kandeler E, Tscherko D, Stemmer M, Schwarz S, Gerzabek MH (2001) Organic matter and soil microorganisms - investigations from the micro- to the macro-scale. Aust J Agric Res 52(2):117131

Killham K, Staddon WJ (2002) Bioidicators and sensors of soil health and the application of geostatistics. In: Burns RG, Dick RP (eds) Enymes in the environment, activity, ecology and applications. Marcel Dekker, New York, pp 391-405 
Kizilkaya R, Așkin T (2007) The spatial variability of soil dehydrogenase activity: a survey in urban soils. Agriculturale Consppectus Scientificus 72:89-94

Leirós MC, Trasar-Cepeda C, Seoane S, Gil-Sotres F (2000) Biochemical properties of acid soils under climax vegetation (Atlantic oakwood) in an area of the European temperate - humid zone (Galicia, NW Spain): general parameters. Soil Biol Biochem 32:733-745

Lin H, Wheeler D, Bell J, Wilding L (2005) Assessment of soil variability at multiple scales. Ecol Model 182:271-290

Makoi JHJR, Ndakidemi PA (2008) Selected soil enzymes: examples of their potential roles in the ecosystem. Afr J Biotechnol 7:181-191

Melero S, Ruiz Porras JC, Herencia JF, Madejon E (2006) Chemical and biochemical properties in a silty loam soil under conventional and organic management. Soil Tillage Res 90:162-170

Morris SJ (1999) Spatial distribution of fungal and bacterial biomass in southern Ohio hardwood forest soils: fine scale variability and microscale patterns. Soil Biol Biochem 31:1375-1386

Mulla DJ (1989) Soil spatial variability and methods of analysis. In: Renard C, Van Den Beldt J, Parr JF (eds) Soil, crop and water management in the Sudano-Sahelian Zone. ICRISAT, Patancheru, pp 241-252

Mulla DJ, McBratney AB (2000) Soil Saptial Variability. In: Malcolm E, Sumner J (eds) Handbook of soil science. CRC Press, Boca Raton, pp A321-A352

Mummey DL, Stahl PD, Buyer JS (2002) Soil microbiological properties 20 years after surface mine reclamation: spatial analysis of reclaimed and undisturbed sites. Soil Biol Biochem 34:1717-1725

Nannipieri P, Kandeler E, Ruggiero P (2002) Enyme activities and microbiological and biochemical processes in soil. In: Burns RG, Dick RP (eds) Enymes in the environment activity, ecology and applications. Marcel Dekker, New York, pp 1-38

Parkin TB (1993) Spatial variability of microbial processes in soil - a review. J Environ Qual 22:409-417

Quilchano C, Maraňón T (2002) Dehydrogenase activity in Mediterranean forest soil. Biol Fertil Soils 35:102-107

Rossel D, Tarradellas J, Bitton G, Morel JL (1997) Use of enzymes in soil ecotoxicology: a case for dehydrogenase and hydrolytic enzymes. In: Tarradellas J, Bitton G, Rossel D (eds) Soil Ecotoxicology. CRC Press, Boca Raton, pp 179-206

Röver M, Kaiser EA (1999) Spatial heterogeneity within the plough layer: low and moderate variability of soil properties. Soil Biol Biochem 31:175-187

Saetre P (1999) Spatial patterns of ground vegetation, soil microbial biomass and activity in a mixed spruce-birch stand. Ecography 22:183-192

Schinner F, von Mersi W (1990) Xylanase-, CM-cellulase- and invertase activity in soil: an improved method. Soil Biol Biochem 22:511-515

Smoliński S, Długosz J, Piotrowska A, Zamorski R (2008) Spatial variability of soil dehydrogenases and cellulses activities in a field scale. Pol J Soil Sci 41(1):73-80

Soil Survey Staff (1999) Soil taxonomy. A basic system of soil classification for making and interpreting soil surveys. Agricultural handbook 436, natural resources conservation service. USDA, Washington DC

Staddon WJ, Locke MA, Zablotowicz RM (2004) Spatial variability of cyanazine dissipation in soil from a conservation-managed field. In: Nett MT, Locke MA, Pennington DA (eds) Water quality assessments in the Mississippi Delta, regional solutions, national scope. ACS sympoium series 877 . American Chemical Society, Washington, pp 179-193

Stenger R, Priesack E, Beese F (2002) Spatial variation of nitrate-N and related soil properties at the plot scale. Geoderma 105:259 275

Thalmann A (1968) Zur Methodik der Bestimmung der Dehydrodgenaseaktivität im Boden mittels Triphenyltetrazoliumchlorid (TTC). Landwirtsch Forsch 21:249-258

Usowicz B (1999) Application of geostatistical analysis and fractal theory for the investigation of moisture dynamics in soil profile of cultivated field. Acta Agrophys 22:229-243

Usowicz B, Hajnos M, Sokołolwska Z, Józefaciuk G, Bowanko G, Kossowski J (2004) Spatial variability of physical and chemical soil properties in a field and commune scale. Acta Agrophys 3:5-90

Wilding LP (1985) Spatial variability: its documentation, accommodation, and implication to soil surveys. In: Nielsen DR, Bouma J (eds) Soil spatial variability. Pudoc, Wageningen, pp 166-194 